\title{
CUSTOM ON DEMAND 3D PRINTING OF FUNCTIONAL MICROSTRUCTURES
}

\author{
L. Jonušauskas, E. Skliutas, S. Butkus, and M. Malinauskas \\ Laser Research Center, Department of Quantum Electronics, Faculty of Physics, Vilnius University, \\ Sauletekio 10, LT-10223 Vilnius, Lithuania \\ E-mail: linas.jon@gmail.com
}

Received 22 May 2015; accepted 29 September 2015

\begin{abstract}
Rapid development in 3D printing technologies promises a cheap and simple yet reliable way for producing various components and structures for research in numerous science fields. This work is dedicated to investigate the possibility to use fused filament fabrication based 3D printing to fabricate microchannels for microfluidical applications as well as diverse 3D scaffolds for biomedical applications. We also examine the possibility to further improve fabricated structures by employing an ultrafast laser, namely by laser light filamentation and using direct laser writing. Results of this study are discussed in detail and outlook for further work in this field is given.
\end{abstract}

Keywords: 3D printing, microfluidics, lab on chip, regenerative medicine, laser

PACS: $81.16 . \mathrm{Nd}, 81.05 . \mathrm{Mh}$, 42.62.Cf

\section{Introduction}

In the last decade the scientific community saw rapid development of a wide variety of interdisciplinary science fields such as microfluidics [1]], biomedicine [2], micromechanics [3] and so on. In order to continue developing these fields new engineering solutions, device designs, as well as fabrication technologies and methods were created. Currently there is a great interest in transferring the knowledge and know-how from laboratories to widespread use. However, one of the main difficulties in doing so is fabrication methods used to create structures for the aforementioned applications. In most cases these technologies are expensive, too restrictive in spatial geometry [4] 5] or too slow [6] to produce high quantities of cheap microfluidical or biomedical structures such as microchannels or scaffolds for stem cell growth.

During the period of the past several years a relatively new fabrication technology started to emerge in widespread use -3D printing (3DP) [ [7]. 3DP can be realised using several methods, including fused filament fabrication [8]. In contrast to UV lithography [4], soft lithography [5] or laser material microprocessing [9] $3 \mathrm{DP}$ is rather simple, cheap, does not require expensive materials and clean room facilities to operate. Current- ly one can buy a new commercially available 3D printer for around 1000-1500 Euros [10]. One of the materials that such 3DP uses is polylactic acid (PLA). This material is not only cheap (less than 20 Euros for one kilogram), but it is also biocompatible, transparent and could be processed using lasers [11].

In this work we wanted to test the possibility to use 3DP in microfluidical structure fabrication as well as to investigate what kind of scaffolds and micromechanical structures we can create for biomedicine applications [12]. We also tested the possibility to further modify shapes of 3DP manufactured structures by cutting them using laser light filamentation (LLF) [13]. Finally we attempted to integrate fine functional microelements into 3D printed channels using direct laser writing (DLW) [9]. All results are discussed in detail and outlook for further perspectives in this field is given.

\section{Methods and materials}

Focus of this work was placed on a 3DP Ultimaker Original. As mentioned before, this 3DP applies the fused filament fabrication technology (Fig. 1), which is based on the principle of heating a thermoplastic (in this work PLA) above its melting point (in 


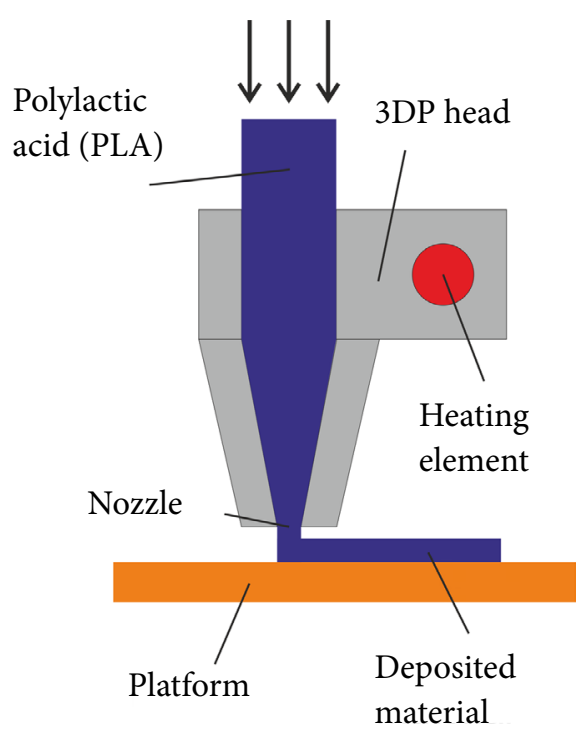

Fig. 1. Schematic representation of the 3DP process using fused filament fabrication technology applied in this work.

our case PLA was heated to $210{ }^{\circ} \mathrm{C}$ ) and pushing it through a fine nozzle (here the nozzle had a diameter of $400 \mu \mathrm{m}$ ). While still hot, the thermoplastic is deposited on a special platform. Then, without a heat source and additionally cooled by a fan, PLA quickly hardens and stays on the platform. 3D structure is obtained by positioning the nozzle in relation to the platform while depositing PLA on it. Positioning offers the highest single layer positioning resolution of $20 \mu \mathrm{m}$, has a maximum build volume capacity of $23 \times 22.5 \times 20.5 \mathrm{~cm}^{3}$ and ensures nozzle position precision in the $x, y$ and $z$ directions of $12.5 / 12.5 / 5 \mu \mathrm{m}$, respectively. To control nozzle positioning we utilized the software provided with this 3DP called Cura (although 3DP can also be controlled directly by using programs written in the g-code). Cura takes the stl file that was created using other programs (AutoCAD, Solidworks, etc.), slices it to layers spaced apart by a distance controlled by the 3DP operator and then optimizes the whole fabrication process by using its own algorithms thus generating the corresponding g-code which is read by machine during the fabrication process. Such an approach is very user-friendly yet does not allow to change much fabrication parameters or fabrication optimisation algorithms. After the g-code is generated, it can be transfered to 3DP directly via a USB port or via a Secure Digital (SD) memory card.

For cutting 3D printed structures we used LLF (Fig. 2). This method is based on the principle of laser light filamentation in water. To achieve this, femtosecond laser light is guided by mirrors that are controlled by galvo motors to an $\mathrm{f}$-theta lens. The lens focuses the laser light in the water thus creating a light filament which cuts through the PLA sample. Experimental setup and parameters used are discussed in another work by our group [8]. Finally, to create functional microstructures that could later be integrated into 3DP fabricated microchannels, we used DLW (Fig. 3). This

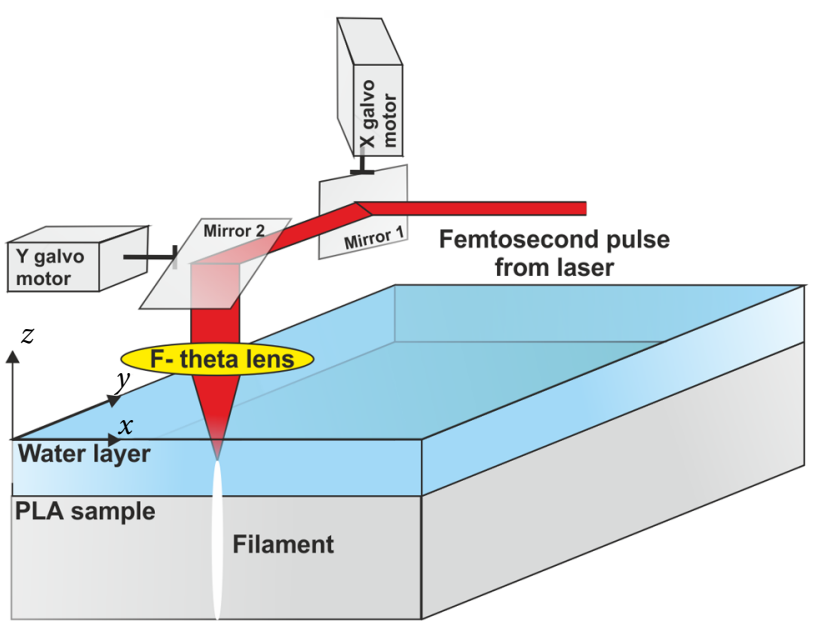

Fig. 2. Principle of cutting by applying LLF: femtosecond laser light is guided by mirrors controlled by galvo motors to an $\mathrm{f}$-theta lens. The lens focuses the laser light in the water thus creating LLF which cuts through the PLA sample.
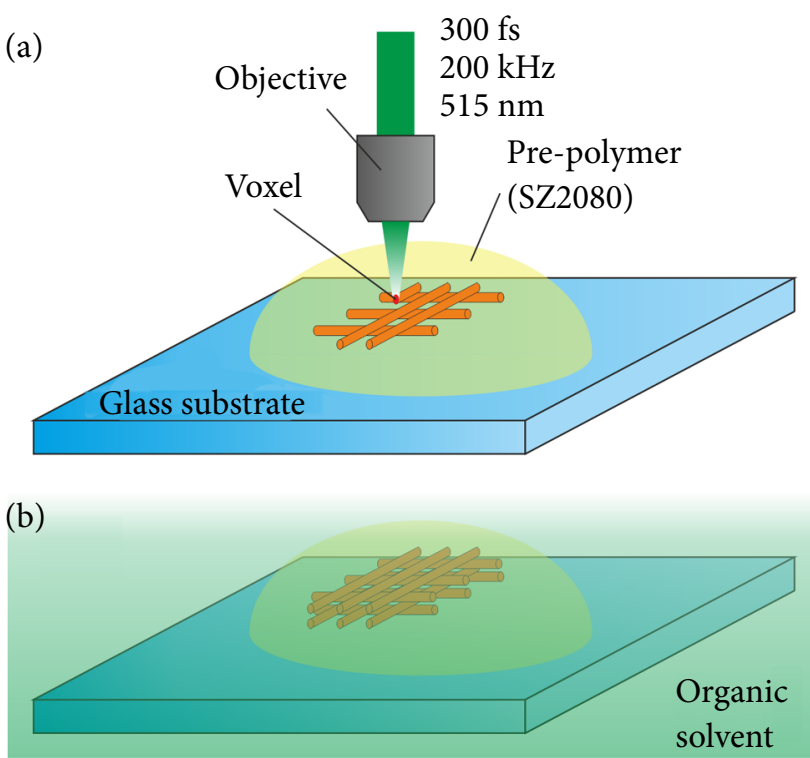

(c)

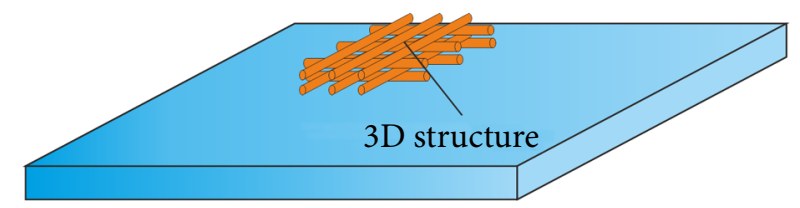

Fig. 3. Principle of DLW: (a) is focusing of laser light and structure fabrication, (b) is development; (c) is revealing of the free standing 3D structure. 
technology is based on the principle of tightly focusing the laser beam to a special pre-polymer material (Fig. B(a)). In the focal point, because of high light intensity $\left(\sim \mathrm{TW} / \mathrm{cm}^{2}\right)$, nonlinear processes start to take place. These processes start the photopolymerization reaction that changes the material in the focal point, forming a volume pixel (otherwise known as voxel). The material around the focal point, however, stays unaffected. Because of this, by positioning the sample in relation to the focal point, we can point-by-point create structures of an arbitrary 3D shape with spatial resolution as high as tens of nanometres [14]. After the fabrication process the whole sample is submerged into an organic solvent which washes out all the unpolymerized material (Fig. 3(b)) thus revealing the free standing 3D structure (Fig. 3(c)). The light source employed in this work was the femtosecond laser Pharos (Light Conversion Ltd.) operating at a wavelength of $515 \mathrm{~nm}$ (the second harmonic), $300 \mathrm{fs}$ pulse duration and $200 \mathrm{kHz}$ repetition rate. Samples were positioned using Aerotech stages (ALS130-110-X,Y in $x, y$ axis, ALS130-60-Z in $z$ axis). For light focusing we used a 63x 1.4 numerical aperture (NA) objective. The material processed using DLW was the nonphotosensitized hybrid organic-inorganic polymer SZ2080. We have chosen this material because of its superb characteristics such as ultra low shrinkage during development [15], transparency [16], biocompatability [17, 18],
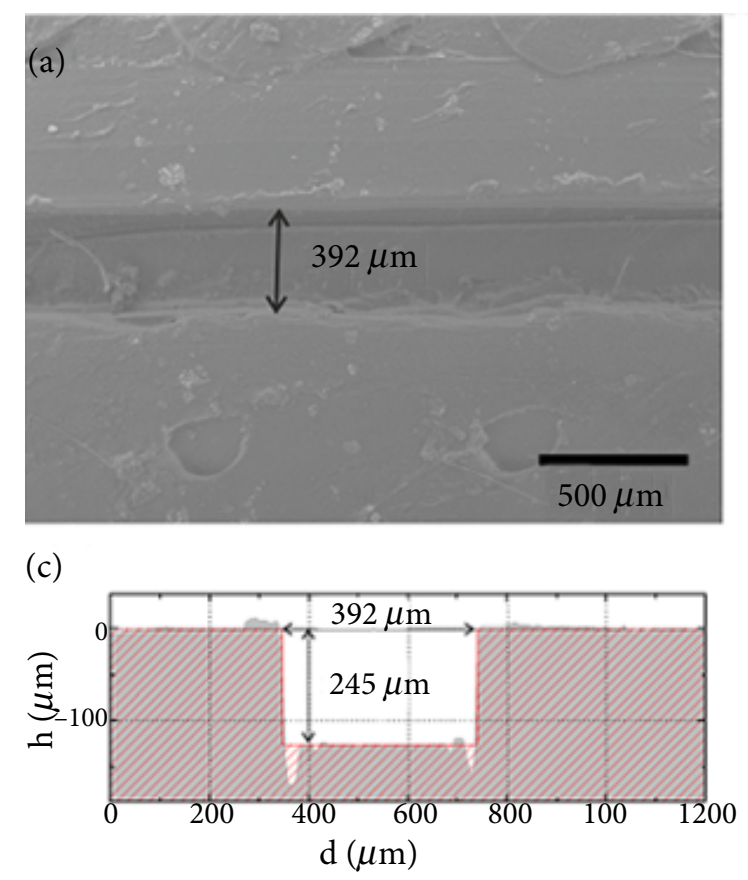

high optical damage threshold [19] and the possibility to structure it without added photoinitiators [20, 21] which eliminates their absorption and toxicity from the material. After the fabrication it was developed in 4-methyl-2-pentanone (PEN). Details on exact experimental setup can be found elsewhere [22].

For sample characterization we used a scanning electron microscope (SEM) TM-1000 (Hitachi).

\section{Results}

\section{1. $3 D$ printing of microchannels}

We began our work by fabricating a straight channel with the smallest possible height and width. In this and all other experiments with 3DP we used the Cura software and models created using AutoCAD. The fabrication speed was $30 \mathrm{~mm} / \mathrm{s}$ and the layer height was $50 \mu \mathrm{m}$. Our results showed that we could reliably fabricate a channel with a depth of $250 \mu \mathrm{m}$. We also managed to create a channel that had a width of $256 \mu \mathrm{m}$, making it nearly square and smaller than the nozzle of 3DP (Fig. A(b), (d)). On the other hand, such a result proved to be hard to recreate using the same fabrication parameters.

Further investigation showed that the channel which had a width of about $392 \mu \mathrm{m}$ and a depth of $250 \mu \mathrm{m}$ had much better repeatability (Fig. 4 (a), (c)).
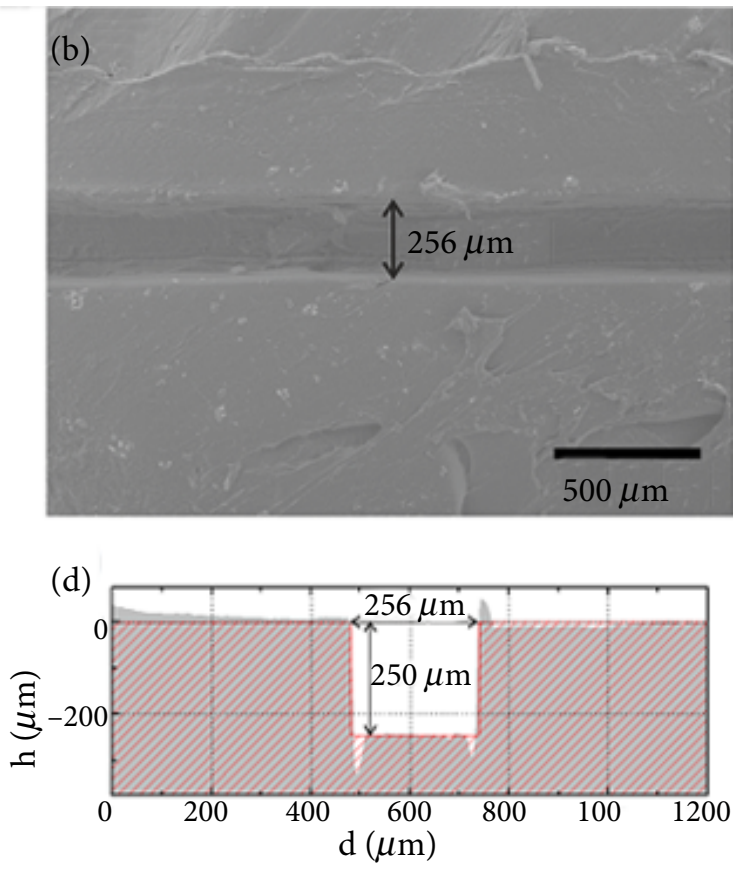

Fig. 4. SEM images of the channels that have a width of $392 \mu \mathrm{m}$ (a) and $256 \mu \mathrm{m}$ (b) and the profiles of the channels created in this work: (c) is the channel with a width of $392 \mu \mathrm{m}$; (d) is the channel with a width of $256 \mu \mathrm{m}$. The grey area and arrows show the measured profile, red lines show a theoretically approximated profile. 
Because of this reason such a channel was used in further experiments. Yet, even with better repeatability, there were severe defects on the ends on such channels (Fig. 5) - in both 256 and $392 \mu \mathrm{m}$ width channels one end of the channel was wider than the rest of the channel and the other end was clogged. This was due to imperfect fabrication optimization in the controlling software.
The next step in our work was attempt to manufacture channels that had more complex configuration. Examples that we fabricated were X-shaped intersection (Fig. 6(a)), intersection where the angle between channels was $90^{\circ}$ (Fig. 6(b)) or $90^{\circ}$ turn (Fig. 6(c)). The results were poor: the shape and quality of such structures were unsatisfactory
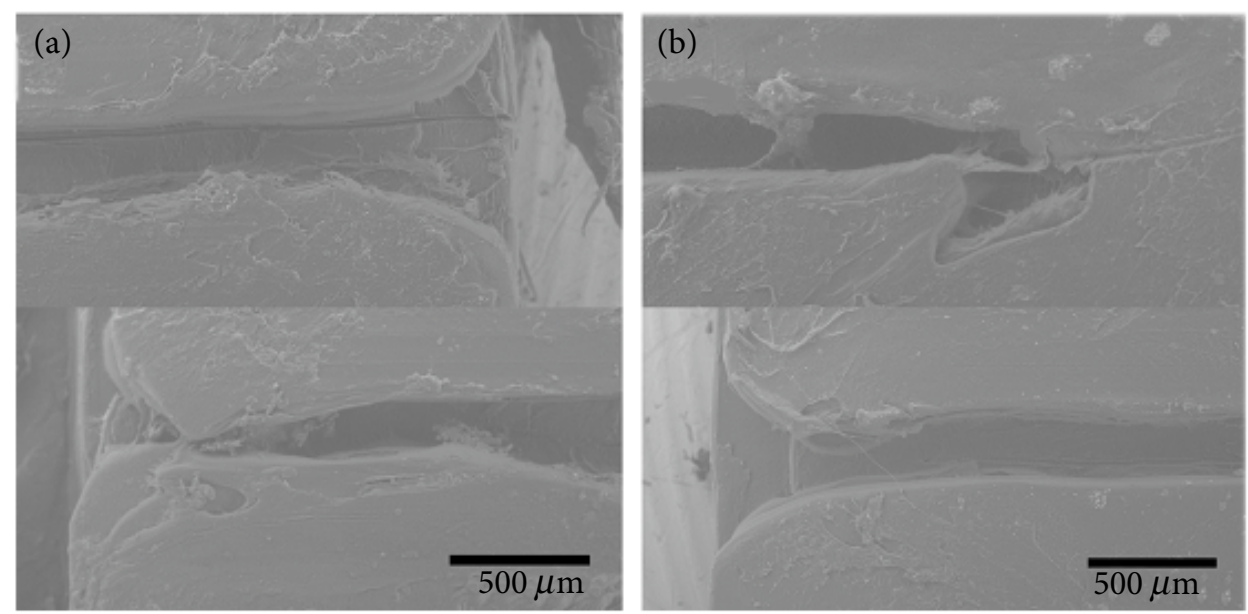

Fig. 5. Ends of (a) $392 \mu \mathrm{m}$ wide and (b) $256 \mu \mathrm{m}$ wide channels. When fabricating channels with 3DP one of the ends was always clogged, while the other ended up being wider than the rest of the channel.
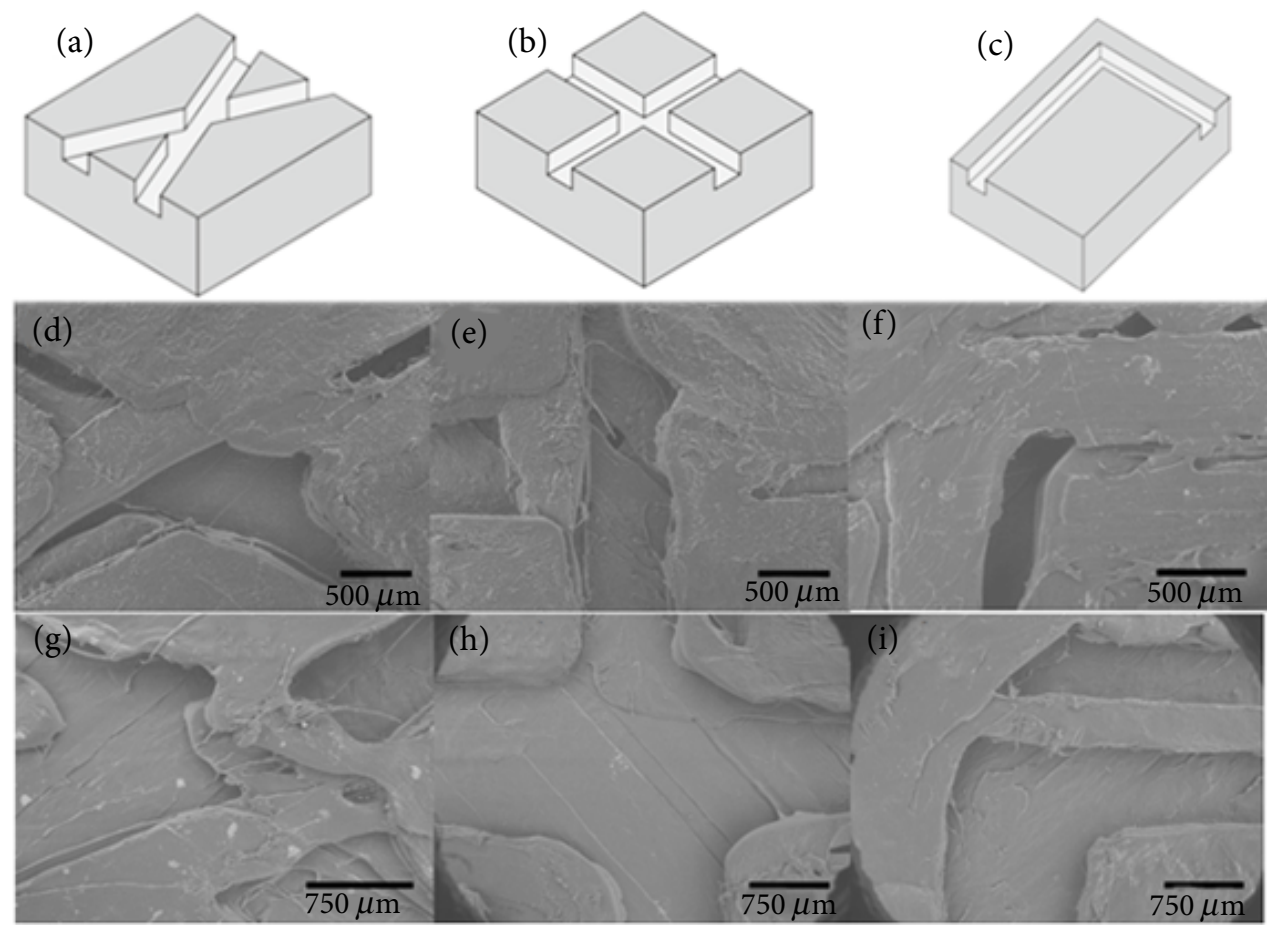

Fig. 6. Representations of the channel shapes that we produced: $\mathrm{X}$ shaped intersection (a), intersection where the angle between channels was $90^{\circ}(\mathrm{b})$ and $90^{\circ}$ turn (c). (d-f) are corresponding structures fabricated using $3 \mathrm{DP}$ with clearly visible defects (theoretical channel width $400 \mu \mathrm{m}$, depth $250 \mu \mathrm{m})$; (g-i) the same channels with their width increased twofold - quality is still unsatisfactory. 
(Fig. 6(d-f)). However, at this point we wanted to know if it was the fault of 3DP and its limitations or it was actually due to poor optimization of fabrication algorithms of the software that we were utilizing. In order to test this we increased the channel width twofold and attempted to fabricate same structures again. The results showed only marginal improvement in quality (Fig. $6(\mathrm{~g}-\mathrm{i})$ ) which allows us to believe that these results are due to manufacturing algorithms of the software and not limitations of 3DP itself. This is important because fabrication programs for 3DP could be created using any software that is capable of exporting g-code to 3DP thus allowing to eliminate defects associated with the software that is provided by creators of this 3DP.

Finally, we proposed and tested a simple yet effective method of attaching 3DP structures to glass substrates (Fig. 7). First, we melted a small amount of PLA on glass. After that, we pressed the 3D printed structure on it and immediately removed the heat source. This allowed us to firmly attach the PLA structure to glass without using any glue or materials other than PLA. It also has no negative impact on the $3 \mathrm{D}$ printed structure because exposure to heat is too short to affect the whole structure. We might also add that such an approach could be used to seal the channels manufactured using 3DP as well.

(a)

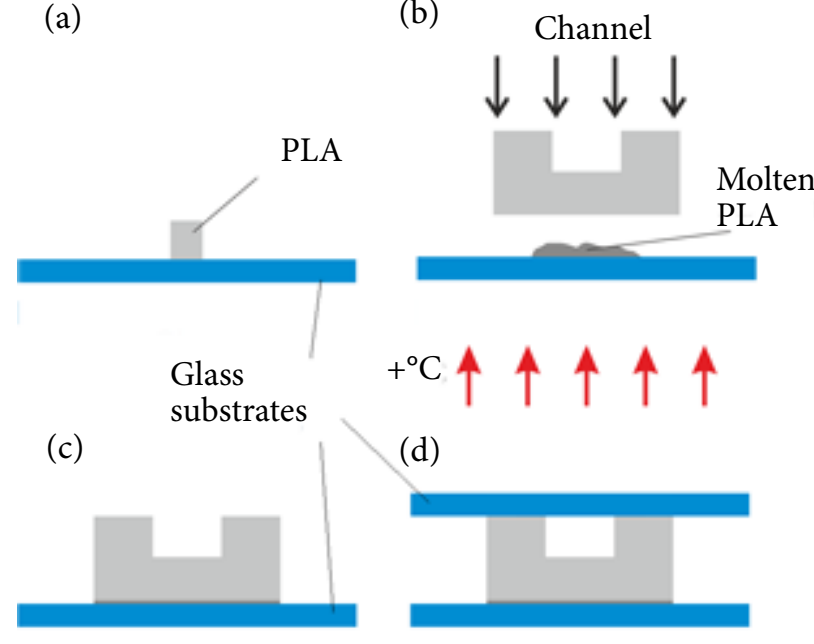

Fig. 7. Process of the 3DP created structure attachment to the glass substrate using heated PLA. (a) A small amount of PLA is placed on the glass substrate. (b) PLA on the glass is heated to the melting point. After it is melted, the $3 \mathrm{D}$ printed structure is pushed on it and the heat source is removed. (c) When the bottom PLA layer is cooled, it firmly attaches the 3D printed structure to the glass substrate without any additional glue or materials. (d) This method can also be utilized to seal the channel.

\subsection{D printing of scaffolds}

The chosen objects for manufacturing were of woodpile geometry. Such architecture is an exemplification of a true structure which has an internal 3D geometry and certain material-air volume fraction (filling ratio). The selected set of manufacturing parameters enabled a repeatable production of woodpiles having $1200 \mu \mathrm{m}$ lateral and $400 \mu \mathrm{m}$ axial periodicities. The obtained line width and height were 400 and $200 \mu \mathrm{m}$, respectively. Logs are made from two such lines fabricated subsequently in the vertical direction, thus the resulting $\log$ height is $400 \mu \mathrm{m}$.

We chose three different 3D microarchitectures: woodpile (BCC), woodpile (FCC) and a rotating woodpile $\left(60^{\circ}\right)$. In the case of the first geometry, each layer consists of parallel logs which are rotated $90^{\circ}$ for every next layer. In the second geometry, every layer is additionally shifted half of the period in respect to the previous parallel log layer (pre-previous). And in the last one, each layer is rotated $60^{\circ}$ in respect to the previous one. Such internal geometries represent common woodpile structure variations [23]. The SEM micrographs of the resulting objects are shown in Fig. $8(\mathrm{a}-\mathrm{c})$, top and $(\mathrm{d}-\mathrm{f})$, oblique views, respectively.

The width of an extruded log was always larger at the cross-sections, with a previously formed log oriented perpendicularly. This is caused by surface tension, viscosity and temperature gradients of the thermopolymer, as it is cast onto a previously deposited log. The contact points between old and freshly extruded logs create cooling points with surface tension pulling a liquid polymer by surface tension gradient towards colder regions. This is an effect similar to the so-called "repolymerization" 24] observed in DLW lithography, where overexposed regions seem to self-form repetitive structures in 1D and 2D manners. Despite that, such $\log$ pile micro-sieve structures having undercuts were successfully manufactured without any sacrificial substructures or support materials. This enables straightforward fabrication of 3D structures with the desired internal geometry without post-processing, such as acetone vapour polishing, developing or heating and mechanical removal of the undesired material. Since the formation of the final 3D structure is controlled by thermoelastic flow and relaxation, an ambient temperature can influence fabrication although this can be easily solved by a simple enclosure of the manufactured sample [8].

\subsection{Laser enhanced 3DP structures}

3DP produced structures can be further enhanced using laser light. In our case we used LLF cutting 

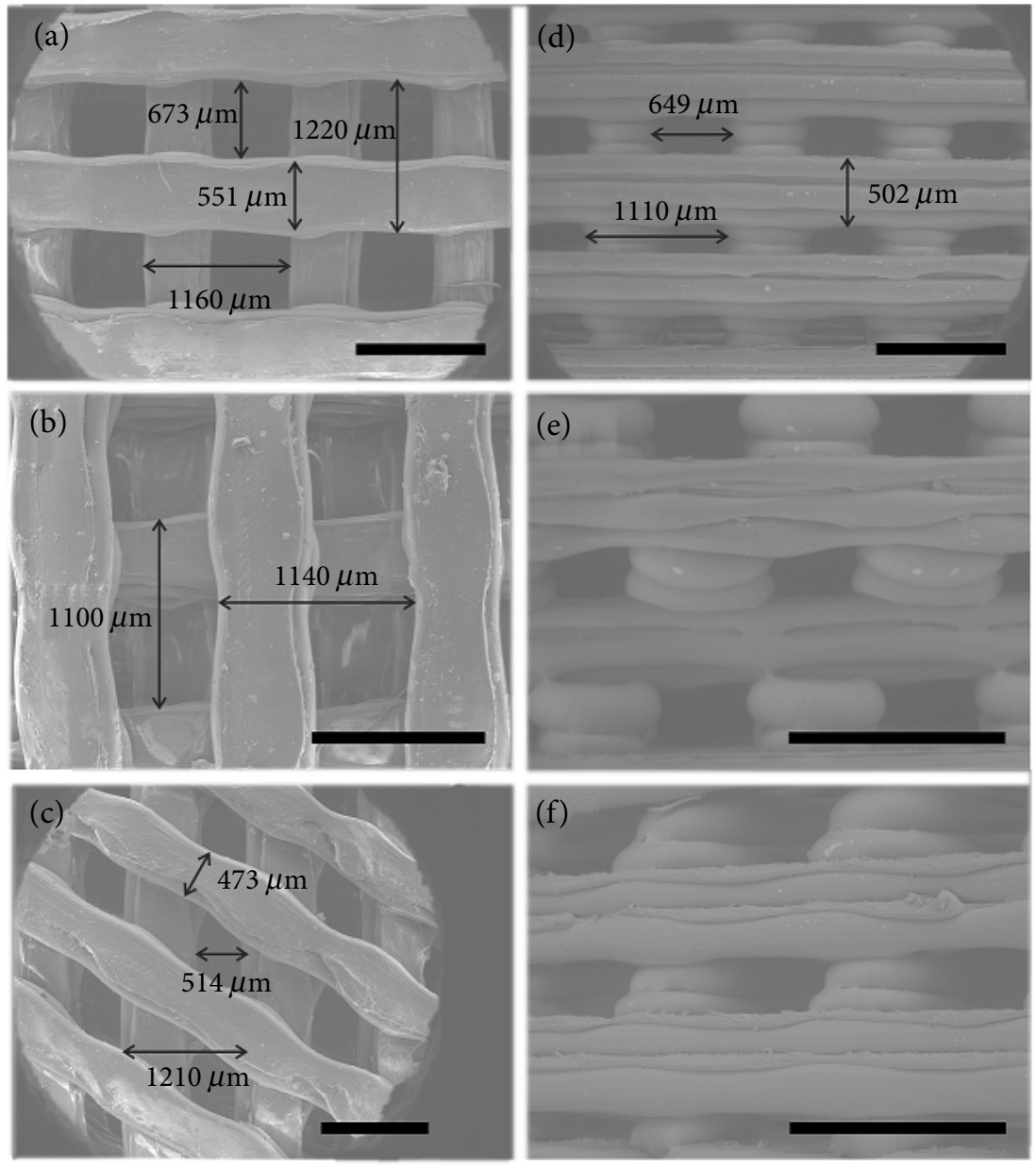

Fig. 8. SEM micrographs of 3D microarchitectures: woodpile (BCC), woodpile (FCC) and a rotating woodpile $\left(60^{\circ}\right)$; top and oblique views, $(\mathrm{a}-\mathrm{c})$ and $(\mathrm{d}-\mathrm{f})$, respectively. All the scale bars are $1 \mathrm{~mm}$ long.

to improve the shape of the 3DP structures and DLW which allows one to incorporate additional functional elements into the $3 \mathrm{D}$ printed structures.

In this work we applied LLF cutting to bulk PLA structures which were more than $1.3 \mathrm{~mm}$ thick. It was either the $256 \mu \mathrm{m}$ wide microchannel (Fig. 9) or the woodpile structure (Fig. 10). For the case of the channel such cutting allowed us to further inves-

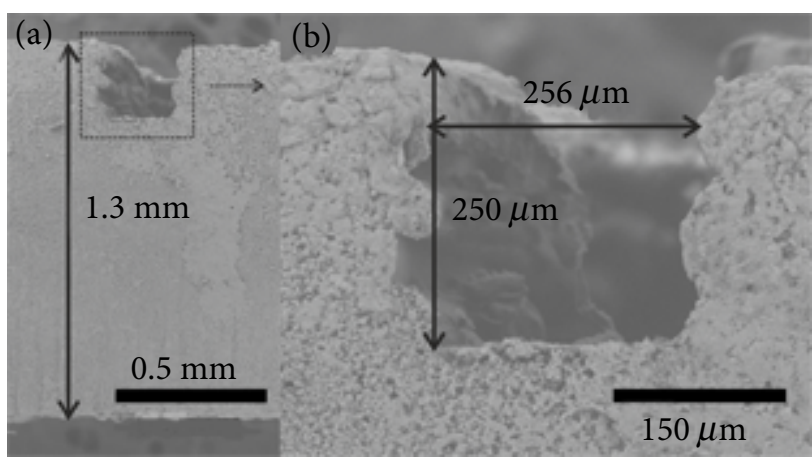

Fig. 9. (a) is the cross-section of the whole PLA structure with the channel cut using laser light filamentation; (b) is the real profile of $256 \mu \mathrm{m}$ wide channel showing inconsistencies. tigate its profile. It also could be used to cut channel ends which can sometimes be clogged during the fabrication process. By cutting woodpile structures it is possible to greatly improve their effectiveness as implants for biomedicine by ensuring that the shape of such structure perfectly matches the shape required. We also noticed that the internal geometry of the PLA structure had no negative effect on the quality of such cutting.

Before attempting to integrate any structure into channels using DLW we first produced prototype

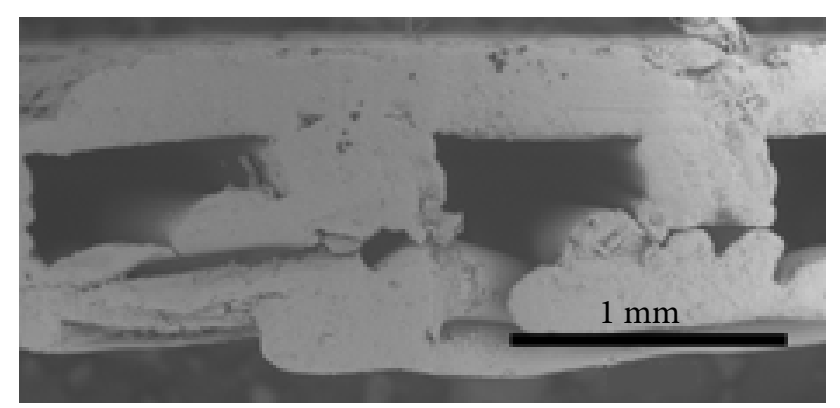

Fig. 10. The cross-section of the PLA wodpile structure fabricated using 3DP and then cut using LLF. 
structures on the glass substrates. We chose to produce microfilters with various geometries because such structures have great potential to act as passive particle sorters in microfluidical systems. In order to demonstrate the full capabilities of DLW for producing such structures we manufactured onedirectional filters with rectangular (Fig. 11(a)) and complex (Fig. 11(b)) thread configurations as well as a fully $3 \mathrm{D}$ filter that had varying thread geometry in different directions of the filter (Fig. 11(c)). We
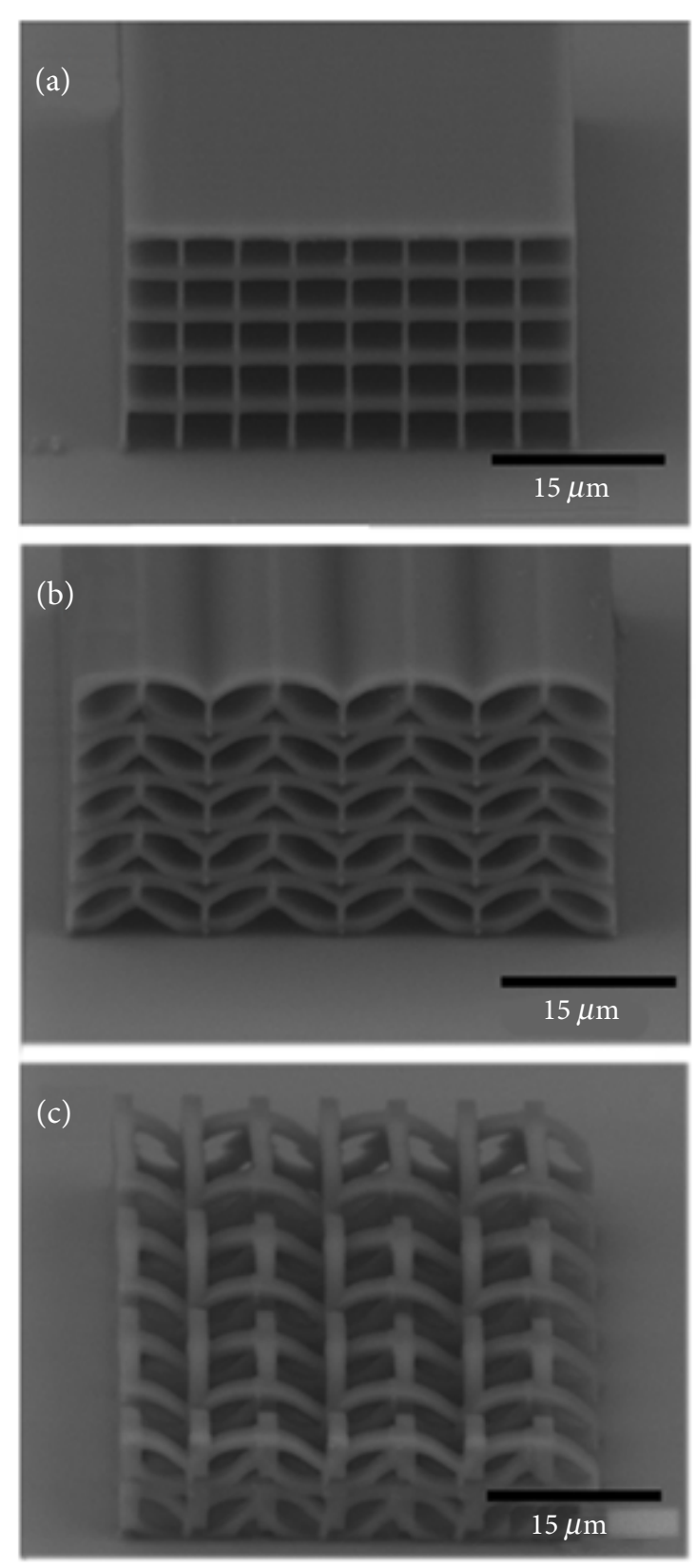

Fig. 11. 3D filters created using DLW. (a) is a one-directional filter with rectangular thread geometry; (b) is a one directional filter with complex thread geometry; (c) is a complex 3D filter with thread geometry depending on the direction of the filter. might also add that if the first two filters are one-directional, the third one can act as a multidirectional filter that filters particles of different sizes and/or shapes coming from more than one direction.

However, when trying to integrate such structures into the channels produced using 3DP, several problems become evident. First, because of the depth of the channel, we were limited to objectives with lower NA, which in turn limits spatial resolution of integrated structures [25]. Moreover, uneven channel sides meant that light focusing at the sides of the channel was difficult. And finally, PEN, which is used to develop SZ2080 structures, has a tendency to affect PLA, which in turn decreases the quality of the channel sides (Fig. 12). However, the first two problems can be solved by using newer 3DP with better fabrication quality. SZ2080 can also be replaced with another material, for example, PEG-DA-258 [26], which is developed in water. So, all in all, there is no fundamental reason why DLW manufactured filters (or other structures) cannot be integrated in 3DP produced channels.

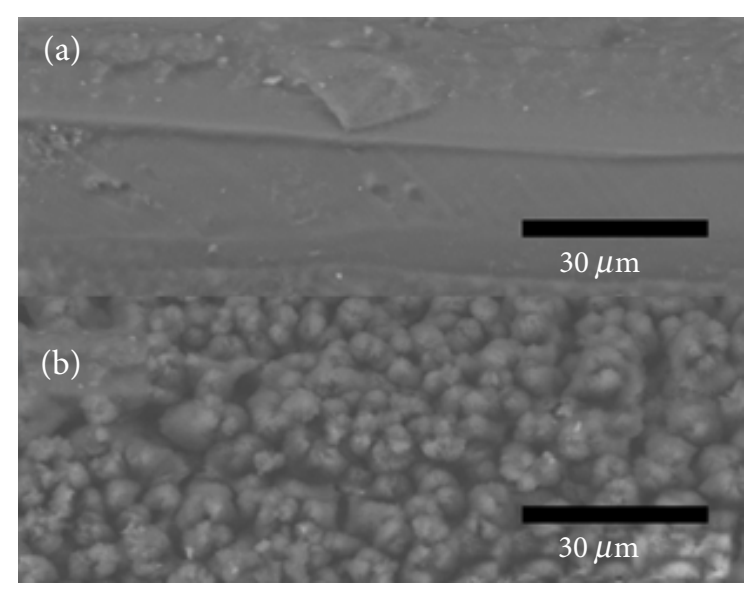

Fig. 12. Effect of PEN used to develop SZ2080 and similar materials to PLA structures: (a) is an unaffected PLA structure; (b) is the surface of the PLA structure after 45 min in PEN.

\section{Discussion}

For a long time the final goal of microfluidical research was creation of the so-called Lab-On-Chip (LOC) type device [27]. Such a device would combine full functionality and precision of huge laboratory equipment into a small cheap chip that could perform various tasks in such fields as medicine [28] or biology [29]. Yet to this day the usage of this type of devices has been limited due to limitations of fabrication techniques that are currently used to produce such devices. Usage of 3DP, especially when combining with other more 
precise fabrication technologies, could be a real game changer in this field and could yield great spread of this technology in the coming years as well as creation of a wide variety of new microdevices, such as passive microparticle sorters which utilize a microfilter in a T-shaped channel junction (Fig. 13).

On the other hand, we could look at this work from the point of improving/supplementing high-precision costly fabrication techniques, such as DLW. DLW was shown to be a powerful tool in creating various functional microdevices, such as photonic structures [30], microoptical elements [31], micromechanical [3] and microfluidical components [32], scaffolds for stem cell growth [18] etc. However, this technology always lacked in terms of fabrication throughput and fabrication cost [6]. The possibility to supplement this state-of-the-art technology with something that can be considered a hobby equipment is an astounding achievement that should be exploited to its maximal potential.

Another important detail we must discuss is the $2.5 \mathrm{D}$ versus $3 \mathrm{D}$ structure usage in LOC type devices. For example, the 3D filter offers a lot of advantages in comparison to 2.5D filters (Fig. 14) that are currently utilized in microfluidics [33], such as better throughput and more rigid construction. What is even more important is that the application of additive manufacturing techniques promises to allow creation of devices which use the whole volume of the structure to perform various tasks rather than
Filter threads

Channel walls

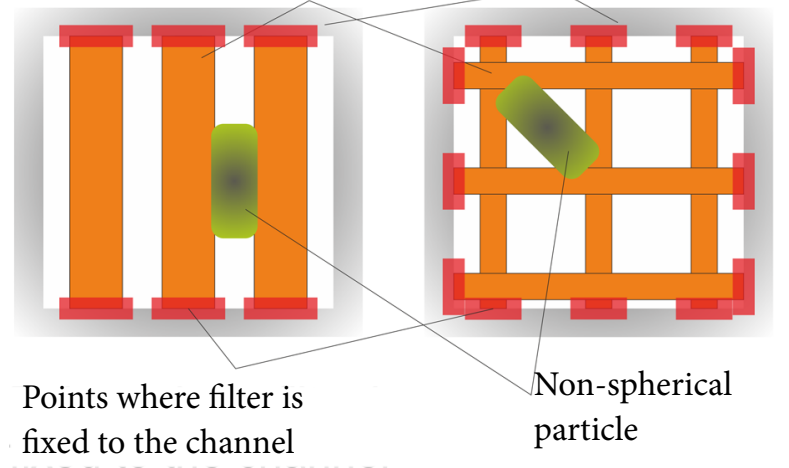

Fig. 14. Comparison of 2.5D and 3D filters: the 3D filter is fixed to all 4 sides of the channel (2.5D to only two) and the spacing between threads in the $3 \mathrm{D}$ filter has to be smaller than the biggest dimension of the particle we want to filter (in 2.5D the spacing has to be smaller than the smallest dimension of the particle). This means that the 3D filter has better throughput (less of the channel cross-section is blocked by it) and is generally more rigid than the $2.5 \mathrm{D}$ filter.

only using their upper surface. This in turn allows us to talk about transition from Lab-On-Chip type structures to Lab-In-Chip devices. Evolution like this should bring great increase in efficiency of such devices without increase in their size (in comparison to current LOC devices).

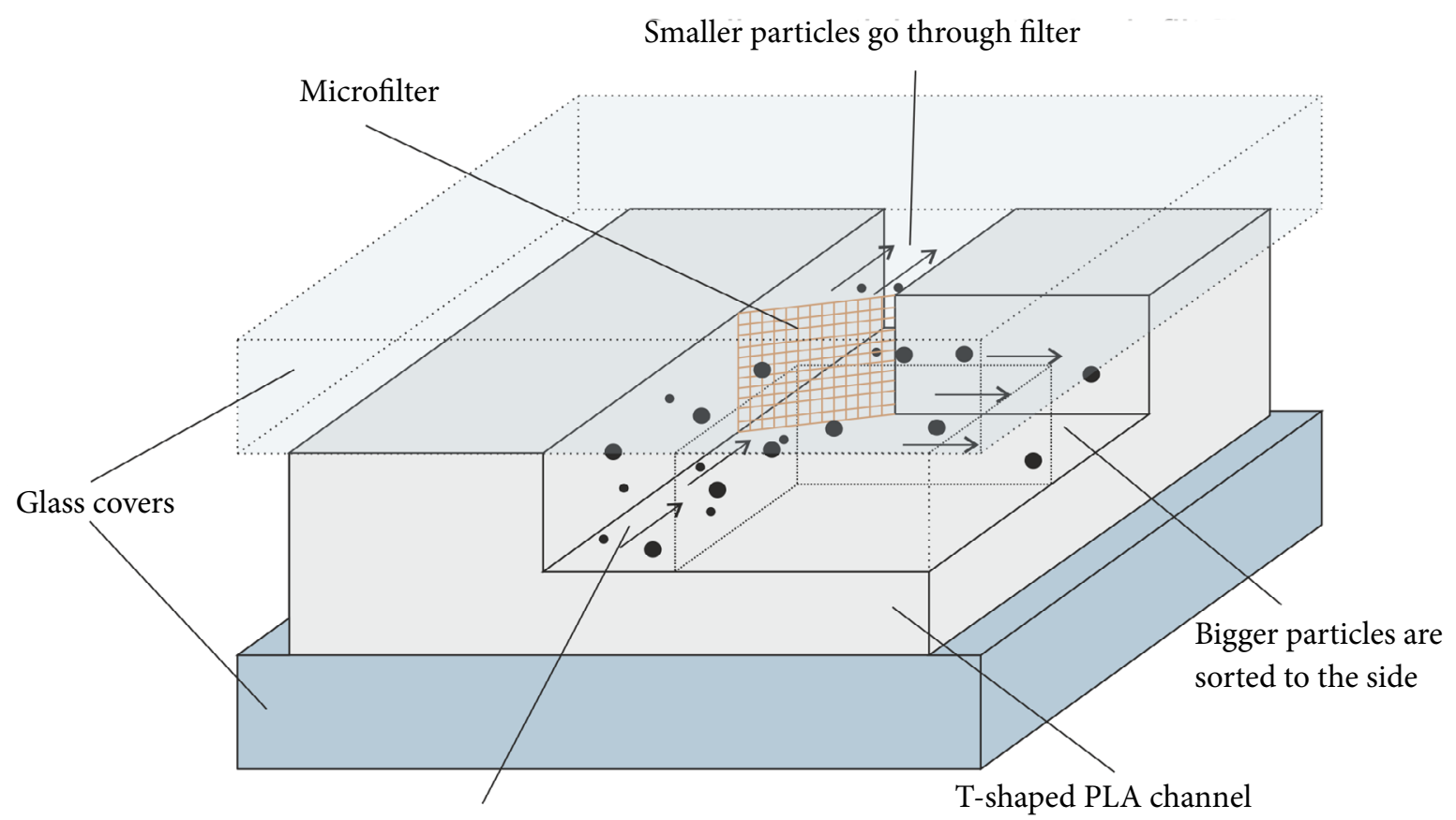

Liquid with microparticles of two different sizes

Fig. 13. Principle of a microparticle sorter based on a T-shaped channel junction and a microfilter. 
Finally, biomedical research could also greatly benefit from application of 3DP [34]. Scaffolds for stem cell growth were produced before, using various technologies [35, 17], yet most of them either struggled to create sufficient numbers of required structures for research in this field, or created structures lacked spatial resolution and/or geometry needed for the best possible result [17]. Application of 3DP combined with other high precision technologies that could further decorate 3DP produced structures could greatly improve this situation and bring us closer to the artificial tissue transplantation and medicine tailored to the individual needs of the patient.

\section{Summary}

In this work we demonstrated the possibilities and limitations of 3DP in creating structures for microfluidics and biomedicine. We also discussed how these structures can be further improved using laser nanolithography and nanomachining. Although there are still difficulties in producing such structures and combining them with DLW, there is no fundamental reason why this could not be done, and, at this point, it requires to only resolve a few technical difficulties.

\section{Acknowledgements}

L.J. and E.S. acknowledge support by Project "Promotion of Student Scientific Activities" (VP1-3.1ŠMM-01-V-02-003) from the Research Council of Lithuania. This project is funded by the Republic of Lithuania and the European Social Fund under the 2007-2013 Human Resources Development Operational Programme’s Priority 3.

\section{References}

[1] G.M. Whitesides, The origins and the future of microfluidics, Nature 447, 435-411 (2006).

[2] J.J. Grodzinski, Polymers for tissue engineering, medical devices, and regenerative medicine. Concise general review of recent studies, Polymer. Adv. Tech. 17, 395-418 (2006).

[3] T. Buckmann, M. Thiel, M. Kadic, R. Schittny, and $\mathrm{M}$. Wegener, An elastomechanical unfeelability cloak made of pentamode metamaterials, Nat. Comm. 5, 4130 (2014).

[4] C.-H. Lin, G.-B. Lee, B.-W. Chang, and G.-L. Chang, A new fabrication process for ultrathick microfluidic microstructures utilizing SU-8 photoresist, J. Micromech. Microeng. 12, 590-597 (2002).

[5] Y. Xia and G.M. Whitesides, Soft lithography, Annu. Rev. Mater. Sci. 28, 153-184 (1998).
[6] M. Malinauskas, V. Purlys, M. Rutkauskas, and R. Gadonas, Two-photon polymerization for fabrication of three-dimensional micro- and nanostructures over a large area, Proc. SPIE 7204, 72040C-1 (2009).

[7] E. Sachs, M. Cima, J. Cornie, D. Band, J. Bredt, A. Curodeau, T. Fan, S. Khanuja, A. Lauder, J. Lee, and S. Michaels, Three-dimensional printing: the physics and implications of additive manufacturing, CIRP Ann. Manuf. Tech. 42(1), 257-260 (1993).

[8] M. Malinauskas, S. Rekštyté, L. Lukoševičius, S. Butkus, E. Balčiūnas, M. Pečiukaitytè, D. Baltriukienè, V. Bukelskiene, A. Butkevičius, P. Kucevičius, V. Rutkūnas, and S. Juodkazis, 3D microporous scaffolds manufactured via combination of fused filament fabrication and direct laser writing ablation, Micromachines 5(12), 839-858 (2014).

[9] K. Sugioka and Y. Cheng, Femtosecond laser three-dimensional micro- and nanofabrication, Appl. Phys. Rev. 1, 041303 (2014).

[10] https://ultimaker.com/ (2015).

[11] V. Melissinaki, A.A. Gill, I. Ortega, M. Vamvakaki, A. Ranella, J.W. Haycock, C. Fotakis, M. Farsari, and F. Claeyssens, Direct laser writing of 3D scaffolds for neural tissue engineering applications, Biofabrication 3, 045005 (2011).

[12]J. Mačiulaitis, M. Deveikyte, S. Rekštytè, M. Bratchikov, A. Darinskas, A. Šimbelyte, G. Daunoras, A. Laurinavičienè, A. Laurinavičius, R. Gudas, M. Malinauskas, and R. Mačiulaitis, Preclinical study of sz2080 material 3D microstructured scaffolds for cartilage tissue engineering made by femtosecond direct laser writing lithography, Biofabrication 7(1), 015015 (2015).

[13] S. Butkus, E. Gaižauskas, D. Paipulas, Ž. Viburys, D. Kaškelytė, M. Barkauskas, A. Alesenkov, and V. Sirutkaitis, Rapid microfabrication of transparent materials using filamented femtosecond laser pulses, Appl. Phys. A 114(1), 81-90 (2013).

[14] W. Haske, V.W. Chem, J.M. Hales, W. Dong, S. Barlow, S.R. Marder, and J.W. Perry, $65 \mathrm{~nm}$ feature sizes using visible wavelength 3-D multiphoton lithography, Opt. Express 15(6), 3426-3436 (2007).

[15] A. Ovsianikov, J. Viertl, B. Chichkov, M. Oubaha, B. MacCraith, I. Sakellari, A. Giakoumaki, D. Gray, M. Vamvakaki, M. Farsari, and C. Fotakis, Ultralow shrinkage hybrid photosensitive material for two-photon polymerization microfabrication, ACS Nano 2(11), 2257-2262 (2008).

[16] Q. Sun, S. Juodkazis, N. Murazawa, V. Mizeikis, and $\mathrm{H}$. Misawa, Femtosecond laser photopolymerization of photonic and free-movable microstructures in sol-gel hybrid resist, Proc. SPIE 7591, 75910K (2010).

[17]P. Danilevičius, S. Rekštytè, E. Balčiūnas, A. Kraniauskas, R. Širmenis, D. Baltriukienè, 
V. Bukelskiene, R. Gadonas, V. Sirvydis, A. Piskarskas, and M. Malinauskas, Laser 3D micro/nanofabrication of polymers for tissue engineering applications, Opt. Laser Tech. 45, 518-524 (2013).

[18] P. Danilevičius, S. Rekštytè, E. Balčiūnas, A. Kraniauskas, R. Jarasienè, R. Širmenis, D. Baltriukienè, V. Bukelskienè, R. Gadonas, and M. Malinauskas, Micro-structured polymer scaffolds fabricated by direct laser writing for tissue engineering, J. Biomed. Opt. 17(8), 081405 (2012).

[19]A. Žukauskas, G. Batavičiūtè, M. Šciuka, T. Jukna, A. Melninkaitis, and M. Malinauskas, Characterization of photopolymers used in laser $3 \mathrm{D}$ micro/ nanolithography by means of laser-induced damage threshold (LIDT), Opt. Mater. Express 4(8), 16011616 (2014).

[20]R. Buividas, S. Rekštytè, M. Malinauskas, and S. Juodkazis, Nano-groove and 3D fabrication by controlled avalanche using femtosecond laser pulses, Opt. Mater. Express 3(10), 1674-1686 (2013).

[21]S. Rekštytè, L. Jonušauskas, A. Žukauskas, G. Gervinskas, M. Malinauskas, and S. Juodkazis, Three-dimensional nano-structuring of polymer materials by controlled avalanche using femtosecond laser pulses, Proc. SPIE 8972, 897210 (2014).

[22]L. Jonušauskas, S. Rekštytė, and M. Malinauskas, Augmentation of direct laser writing fabrication throughput for three-dimensional structures by varying focusing conditions, Opt. Eng. 53(12), 125102 (2014).

[23] M. Malinauskas, E. Skliutas, A. Šešok, D. Mizeras, L. Jonušauskas, and A. Piskarskas, Tailoring bulk mechanical properties of $3 \mathrm{~d}$ printed objects of polylactic acid varying internal micro-architecture, Proc. SPIE 9505, 95050P (2015).

[24]E. Stankevičius, M. Gedvilas, B. Voisiat, M. Malinauskas, and G. Račiukaitis, Fabrication of periodic micro-structures by holographic lithography, Lith. J. Phys. 53(4), 227-237 (2013).

[25] Y. Liu, P.L. Nolte, and D. Nolte, General 3D microporous structures fabricated with two-photon laser machining, Proc. SPIE 6886, 68860Y (2008).
[26]A. Ovsianikov, M. Gruene, M. Pflaum, L. Koch, F. Maiorana, M. Wilhelmi, A. Haverich, and B. Chichkov, Laser printing of cells into 3D scaffolds, Biofabrication 2(1), 014104 (2010).

[27] P. Abgrall and A.-M. Gue, Lab-on-chip technologies: making a microfluidic network and coupling it into a complete microsystem: a review, J. Micromech. Microeng. 17, R15-49 (2007).

[28]R.B. Fair, Digital microfluidics: is a true lab-on-achip possible? Microfluid. Nanofluid. 3(3), 245-281 (2007).

[29] V. Fleury, Biofluidics of animal morphogenesis: does evolution follow stream lines? Comput. Meth. Biomech. Biomed. Eng. 15(S1), 17-18 (2012).

[30] M.D. Turner, M. Saba, Q. Zhang, B.P. Cumming, G.E. Schroder-Turk, and M. Gu, Miniature chiral beamsplitter based on gyroid photonic crystals, Nature Photon. 7, 801-805 (2013).

[31] A. Žukauskas, M. Malinauskas, and E. Brasselet, Monolithic generators of pseudo-nondiffracting optical vortex beams at the microscale, Appl. Phys. Lett. 103(18), 181122 (2013).

[32] T. Ikegami, R. Ozawa, M.P. Stocker, K. Monaco, J.T. Fourkas, and S. Maruo, Development of optically-driven metallic microrotors using twophoton microfabrication, J. Laser Micro/Nanoeng. 8(1), 6-10 (2013).

[33]P. Sajeesh and A.K. Sen, Particle separation and sorting in microfluidic devices: a review, Microfluid. Nanofluid. 17, 1-52 (2014).

[34] M. Markovic, J. Van Hoorick, K. Hoelzl, M.T. Tromayer, P. Gruber, S. Nuernberger, P. Dubruel, S. Van Vlierberghe, R. Liska, and A. Ovsianikov, Hybrid tissue engineering scaffolds by combination of $3 \mathrm{D}$ printing and cell photoencapsulation, J. Nanotech. Eng. Med. (2015), http://dx.doi.org/ $10.1115 / 1.4031466$

[35]Y. Wang, H.-J. Kim, G.V.-Novakovic, and D.L. Kaplan, Stem cell-based tissue engineering with silk biomaterials, Biomaterials 27(36), 6064-6082 (2006).

\title{
LANKSTUS TRIMATIS UNIKALIŲ FUNKCINIŲ MIKRODARINIŲ SPAUSDINIMAS
}

\author{
L. Jonušauskas, E. Skliutas, S. Butkus, M. Malinauskas \\ Vilniaus universiteto Lazeriniu tyrimu centras, Vilnius, Lietuva
}

\section{Santrauka}

Darbe pristatoma mikrofluidinių ir biomedicininių darinių gamyba naudojant trimati spausdinimą. Aptariamos galimybès ir dèl šio metodo atsirandantys sunkumai gaminant nurodytoms sritims skirtus funkcinius mikrodarinius. Nusakoma, kaip šiuo būdu pagaminti dariniai galètų būti toliau tobulinami naudojant nano- litografiją ir lazerini nanoapdorojimą. Nors šiuo metu egzistuoja keletas techninių problemų, ribojančių trimačio spausdinimo ir tiesioginio lazerinio rašymo derinimą gaminant minètuosius darinius, daroma išvada, kad nèra jokių fundamentalių priežasčių, trukdančių išspręsti šias problemas. 